University for Business and Technology in Kosovo

UBT Knowledge Center

Oct 27th, 10:45 AM - 12:15 PM

\title{
Quality as a subject of study in the field of Management and
}

\section{Education}

Gkarnara Rodoula-Stavroula

University of Aegean, psed17001@aegean.gr

Follow this and additional works at: https://knowledgecenter.ubt-uni.net/conference

Part of the Education Commons

\section{Recommended Citation}

Rodoula-Stavroula, Gkarnara, "Quality as a subject of study in the field of Management and Education" (2018). UBT International Conference. 131.

https://knowledgecenter.ubt-uni.net/conference/2018/all-events/131

This Event is brought to you for free and open access by the Publication and Journals at UBT Knowledge Center. It has been accepted for inclusion in UBT International Conference by an authorized administrator of UBT Knowledge Center. For more information, please contact knowledge.center@ubt-uni.net. 


\title{
Quality as a subject of study in the field of Management and Education
}

\author{
Rodoula- Stavroula Gkarnara \\ University of Aegean, Rhodes \\ Scholar of Onassis Foundation \\ Psed17001@aegean.gr
}

\begin{abstract}
This article attempts to discuss the term of quality both in the Management and the Educational field in order to present the similarities and the differences in the term. The concept of quality was introduced in the 1950 s and 1960s, when the Japanese faced serious problems with the export and sale of their products. Since then, many scientists have dealt with this concept, which has begun to grow in the field of Management and Business. The delimitation of quality has proven to be a complex process, which even today is a controversial issue because of the subjective nature that is given to it. Quality in an organization seems to be perceived as a solution to its problems and in conjunction with costs it determines the competitiveness of the product. The interest in quality has also been transferred to the field of Education - both in higher and further education - in the 1990s. The quality of education has confused educational communities both in Europe and in the wider international context. This can be also proved from the fact that all the European Community states have set the quality of education as a matter of highest priority. During financial difficulties, the school system has been put under the microscope in order to be improved and quality is the catalyst for growth. In education, quality is linked to the achievement of predetermined goals. Therefore, in order to achieve qualitative results, there should be quality input, qualitative teaching methods and psychological / intellectual quality and hence qualitative school units.
\end{abstract}

Keywords: Quality, Business Administration, Management, Education, Schools

\section{Introduction}

In the field of Management, the concept of learning organizations became very popular in the 1990s and until now it has played a crucial role (Ahmad, Sulan \& Rani, 2017: 392), after being promoted as a solution to the problems faced by organizations (Ortenblad, 2015: 163). Garvin (1993: 3) states that a learning organization is "an organization skilled in creating, acquiring and transferring knowledge, and modifying its behavior to reflect new knowledge and insight", while Pedler et al. (1991: 1) described a learning organization as "an organization that facilitates the learning of all 
its members and continuously transforms itself". However, according to Ortenblad (2015: 164), no researcher has identified any specific changes that an organization has to make in order to become "a learning organization" and be engaged with all organizations - although various models have been proposed from time to time. Nonaka \& Toyama (2003: 2) come to support this position by pointing out that this failure is due to the fact that both professionals and employees cannot understand the essence of the process of creating new knowledge.

A school unit is also considered by many scientists to be a kind of organization, as they both share some common features. Such features are; the definition of specific targets, the bureaucratic organization they have, their segregation, their staffing and their promotional policies. There is a hierarchy and rules with which everyone has to comply independently with personal relationships (Ballantine, 1997: 131, 133-136; Bell, 1980: 184). School units are also considered to be learning organizations, as organizational learning is thought to have contributed significantly to school changes, such as training programs, common goals and team effort which are all obvious by the high performance of such schools (Schechter \& Mowafaq, 2013: 505). The issue of quality has been linked to learning organizations through Total Quality Management ( $\mathrm{Yu} \& \mathrm{Wu}, 2009: 39-40)$. The relationship between quality management and learning organizations is obvious since they both promote teamwork, adapt to change, follow the systematic approach and are willing to learn (Ahmad, Sulan \& Rani, 2017: 393). Total Quality Management is based on continuous improvement and requires dedication to knowledge and continuous improvement (Love et al., 2000: 321).

According to the above, the purpose of the article is to summarize the delimitation of quality both in the field of Management and in the field of Education, since both sectors include learning organizations. Nowadays quality is one of the main factors related to the competitiveness of an organization and its success in international markets (Forker, Vickery \& Droge, 1996: 44; Green, 1994: 7), a fact which is also pointed out by Oakland (1997: 25), as the three parameters in which organizations compete are quality, price and tradition. Since quality is a key issue, many scientists from different fields have tried to answer the question of what is quality (Forker, Vickery \& Droge, 1996: 45). However, its orientation has proven to be a fairly complex process (Bowers, Ranganathan \& Simmons, 2018: 52; Green, 1994: 12) and its assessment is influenced both by socio-historical circumstances and by political changes, because quality has been related to changes in society and it seems to be a challenge for schools to reciprocate to wider social changes (Carbines, 1994: 4).

\section{Quality in Management and Business}

The issue of quality began in the early 1950s in Japan, where there was a significant problem in selling products -not because of their price, but because of their lack of quality; so the Japanese focused on quality with the main aim being its 
improvement (Edge, 1997: 560). The movement of total quality was inspired by two Americans, Deming and Juran, who, with statistical methods, attempted to give quality substance through the field of engineering (West-Burnham, 1997: 15). In the field of Management and Business, the current era is particularly critical, as there is a lot of competition in the markets and the demands of customers are continuously growing. In addition, markets have largely deregulated, while globalization is also a major factor (Lai, 2003: 17). Customers are looking for the best possible quality product, because they have a wider choice, more knowledge and know-how (Lai, 2003: 18). A general definition states that quality seems to be related firstly to the type of product or service and secondly to the product itself and whether it serves its purpose without malfunctioning (Winch, 1996: 9). Each quality specialist has proposed different strategies for delimitation, quality improvement and management (Forker, Vickery \& Droge, 1996: 44). Approximately five quality improvement approaches have been identified. The first is the total approach, where quality is identified with excellence (Winch, 1996: 9). It argues that although it is difficult to be clearly defined, it is an absolute concept and can be recognized through experience (Forker, Vickery \& Droge, 1996: 45). Tuchman (1980: 38), also, pointed out that quality means the best possible result, first class and not compatible with something else than that. The second is the product-based approach, where quality is discussed in measurable and accurate terms, and is part of the product characteristics (Winch, 1996: 9).

Quality in an organization seems to be perceived as a solution to its problems (West-Burnham, 1997: 17), while many organizations adopt a market-oriented strategy of abandoning its production-oriented strategy. The new strategy, therefore, focuses on customer satisfaction (Lai, 2003: 17-18). So, the third approach centers around the consumer/ user, who judges the product according to their needs and desires. This approach is identified by a further definition according to which quality is defined as the suitability for use according to the terms of the consumer (OECD, 2011: 7; Statistics Canada, 2002: 2; Green, 1994: 15). Juran (1999: 26) and Oakland (1997: 25) define quality in terms of the degree to which product characteristics meet customer requirements and whether they meet them at all. In order survive on all these disturbances, organizations must be competitive and meet their customers' requirements by offering high quality products and services (Lai, 2003: 17). Philip Crosby is perhaps the most important writer who has influenced both Europe and USA, as he has worked with senior executives and has discovered how an organization can increase its profits by improving quality. For Crosby, quality is directly related to the conformance with requirements rather than the essential quality. $\mathrm{He}$ is more concerned with prevention than with the detection of any defects in production (West-Burnham, 1997: 19). Levitt (1972: 41) and Gilmore (1974: 16) moving at the same wavelength equates quality with conformance to product characteristics / specifications.

In the latter approach in the center is the value of the product -with the quality to be directly related to this value (Winch, 1996: 9). In the early 1800s cheaper products were made of lower quality. In the 1950s, the concept of quality was introduced in the field of Business and since then this concept has also been linked to the price of the product as a key factor for customer choice (Reeves \& Bednar, 1994: 
421). Feigenbaum (1951: 1) highlighted this relationship by stating the fact that quality is related to excellence in proportion to factors, such as product usability and sales price. Abbott (1955: 108) and Broh (1982: 3) complete the Feigenbaum's view by pointing out that the customer will succumb to the best bid on the market, which has these two components mentioned above. Of course, all approaches have their advantages and disadvantages. Each manager should choose the one that will bring the best possible results for his/ her own organization. Customer satisfaction is this factor that has the greatest impact in this field (Reeves \& Bednar, 1994: 435).

From time to time various scientists have suggested some dimensions of quality that can help in understanding and delimiting the term. In fact, the six dimensions set for quality delimitation are: a) relevance b) accuracy c) timeliness d) accessibility e) Interpretability and f) Coherence (Statistics Canada, 2002: 2-3). However, the concept of quality for businesses differs from the concept of quality in education (Chaffee \& Sherr, 1992: 20), as will be discussed in the next section. Garvin $(1984,1987)$ proposed eight dimensions of quality, which are key factors in delimiting and analyzing the term thoroughly:

1. Performance: product's primary characteristics.

2. Features: those characteristics that supplement the products' basic functioning.

3. Reliability: whether the product malfunctioning or failing within a specified time period.

4. Conformance: the degree to which a product's design and operating characteristics meet established standards.

5. Durability: the amount of use that one product gets from another before it deteriorates.

6. Serviceability: speed, courtesy, competence and ease of repairing.

7. Aesthetics: how a product looks, feels, sounds, tastes and/or smells.

8. Perceived Quality: image, reputation and/or references about the product's characteristics.

Forker, Vickery \& Droge (1996: 46) associate each of Garvin's dimensions with the quality approaches mentioned above. The relations are as follow:

Table 1. Correlation of dimensions with approaches.

\begin{tabular}{cc}
\hline Dimensions & Approach \\
\hline Performance, Features & Product based \\
Reliability, Conformance & Manufacturing based \\
Durability, Serviceability & Value based \\
Aesthetics, Perceived Quality & User based \\
\hline
\end{tabular}


Organizations should constantly aim at continuous improvement of their products and innovation in all their functions (Lai, 2003: 17). For Deming, quality is directly linked to continuous improvement often referred to as a reduction in costs as it is considered to be the same as a reduction of defective products. This is why he was opposed to bulk product inspections, since they proved to be financially unprofitable and needless -given that a correction of the product cannot be made afterwards. However, he suggests that special attention has to be paid to customer requirements and to the construction of the product, summarizing his view through 14 principles (West-Burnham, 1997: 20-21)

\section{Quality in education}

The interest in quality was also transferred to education in the late 1980s and early 1990s in both higher and further education (Avci, 2017: 203; West-Burnham, 1997: 16). Bowers, Ranganathan \& Simmons (2018: 59), through a literature review on quality in education, found that there are plenty of quality publications on definitions of the term, quality models, strategies and practices that are or may be used. This is shining proof that quality in education is a key issue. According to Barlosky \& Lawton (1994: 58), quality is "continuous improvement of learning for life" as the school unit through continuous improvement will develop by learning from its mistakes as a learning organization (Cheng \& Tam, 1997: 29). Cheng (1995) claims that educational quality is "the character of the set of elements in the input, process and output of the education system that provides services that fully satisfy both internal and external strategic constituencies by meeting their explicit and implicit expectations." This definition is quite comprehensive and includes many key terms from the Management field. Quality is judged by whether the product achieves the purpose for which it was created (Wittek \& Kvernbekk, 2011: 674).

However, there is a strong concern in the scientific community regarding the variety and objectivity of quality definitions. Quality is described as "a slippery concept" and it's similar to other broad concepts, such as "justice" and "freedom" (Harvey \& Green, 1993: 10). Doherty (2008: 260) and Cryer (1999: 40) argue that quality remains a utopia and - to a great extent- subjective notion, since each person understands it in different ways. Harvey \& Green (1993: 10) also claim that the diversity in boundaries is due to the fact that different people have different perspectives on different things that are under the same umbrella. The views on quality in education differ, as there are many contributors, such as teachers, students, parents, etc., who have different perspectives and expectations (Westerheijden, Stensaker \& Rosa, 2007: 4). A study by Chua (2004: 185) found that parents had a different understanding of the quality of education in relation to pupils and had different expectations. More specifically, both parents and students were interested in post-school vocational rehabilitation, but beyond that, parents were interested in the reputation of the school, while the students were concerned about the quality of teaching. During financial difficulties, the school system is put under the microscope 
in order to be improved (Carbines, 1994: 2). According to Cheng (2017: 153) "quality can be achieved by enhancing academics 'professionalism and students' ability to learn". Quality in education can be a catalyst for development and should be ensured in all areas and in all phases of education. Moreover, quality is established by meeting the needs of all those involved in the educational process (Freeman, 1994: 23). To examine the quality of a school unit, a broader perspective should be adopted on issues related to the objectives of the school, its philosophy, the characteristics of its pupils and the quality of its teachers, its natural resources, the variety of the educational activities and the educational successes (Nevo, 1995: 154).

The concept of quality can either be divided into different pieces or determined on the basis of some indicators ensuring quality (Wittek \& Kvernbekk, 2011: 672). Because of the multidimensional nature of quality, it is necessary to study more than one indicator. The study of a variety of indicators of a school organization will highlight the different expectations and management strategies used for educational quality in a specific environment and under specific conditions (Cheng \& Tam, 1997: 23). The quality of a child's education is directly related to the quality of the school unit itself (Johnson, Wyer \& Gilbert, 1967: 221) and therefore the indicators are directly related to the school unit. For the same purpose, different people will use different indicators to understand educational quality and different strategies to achieve it or at least approach it (Cheng \& Tam, 1997: 23). Brown (1957: 362) states that the starting point for quality education in education is the curriculum, while Ifedili (2015: 23) claims that the quality of education depends on the implementation of educational policy, which includes to a large extent the employment of highly qualified teachers. In addition, the two main factors that affect the quality of a school are the pupils' social relationships with the school and the social orientation of the school class by placing the value of personal success and the role of education as key parameters in attaining achievements related to teachers' targets (Johnson, Wyer \& amp; Gilbert, 1967: 221). By the same reasoning, Nevo (1995: 155) proposes six indicators of school quality assessment. Quality indicators focus on different elements. Others focus on the educational process and others on inputs and outputs. The complexity of educational quality and the lack of official quality indicators lead to deep thinking and doubts in society (Cheng \& Tam, 1997: 22-23). The biggest problem with indicators is that they are often dated, as this can happen with data. They can give answers for past situations, but they cannot be mentioned for the present or the future (Doherty, 2008: 258).

\section{Conclusion}

The concept of quality has universally occupied the international scientific area, given its multidimensional and multifaceted nature. At a time when competitiveness is particularly intense, quality can be a strong ally of an organization by pleasantly surprising customers via the concern about customer satisfaction and the continuous improvement of all its dimensions (Forker, Vickery \& Droge, 1996: 61). Each person 
defines quality differently in different terms and in different circumstances (Lai, 2002: 19; Harvey \& Green, 1993: 10), and as Reeves \& Bednar (1994: 435) mention no definition of quality is appropriate for all fields.

The main question is whether quality management definitions and models can be applied to education (Avci, 2017: 203). Quality approaches from the field of Management may differ, since they correspond to different objects (Owlia \& Aspinwall, 1996: 17). Non-educational organizations - although having several common points - differ from the educational ones, as they have different funding, goals and a different external environment (Green, 1994: 7). Many of the quality models and many business strategies have been adopted and used in education (Chua, 2004: 181), although there are several difficulties. This arises from the fact that education is a public good and it is not some kind of product or skill, which can be used to increase the profits of a business (Turner, 2011: 3). To sum up, quality in Management is more technocratic in relation to quality in Education, which is the result of learning and it is related to children. In Education, although the consumer/ user approac prevails, the approach to quality-value (Winch, 1996: 9), also, lags behind. Quality is judged to be good or bad or based on some comparative terms and this indicates that it's judged by its value (Wittek \& Kvernbekk, 2011: 675). Cheng (2017: 157), due to the findings of five integrated programs, argues that quality related to the management's focus is indifferent to the developmental needs of both students and academics. When applying quality models to education, it is found that students play the role of clients. The difficulty in this case lies in the fact that it is difficult to determine their needs in order to be satisfied. This happens because schools are made up of different groups of pupils, who perceive quality in a different way (Chua, 2004: 181). Another problem is that there is skepticism about the different levels of the students that the school has to deal with, as this does not reflect the level of the organization (Owlia \& Aspinwall, 1996: 17). Finally, educating a person cannot be seen simplistically, as an organization sees the client through terms such as customer satisfaction, because in the former situation, the result cannot be described by quantitative criteria (Turner, 2011: 4).

\section{References}

1. Abbott, L. (1955). Quality and competition. New York: Columbia University Press.

2. Ahmad, A., Sulan, N., \& Abdul Rani, A. (2017). Integration of learning organization ideas and Islamic core values principle at university. The Learning Organization, 24(6), 392-400. doi: 10.1108/tlo-05-2017-0051

3. Avci, E. (2017). Drawing on other disciplines to define quality in bioethics education. Quality in Higher Education, 23(3), 201-212. doi: 10.1080/13538322.2017.1407394

4. Ballantine, J. (1997). The sociology of education (4th ed.). Prentice Hall College.

5. Barlosky, M. \& Lawton, S. (1994). Developing quality schools. Toronto: [Dept. of Educational Administration, Ontario Institute for Studies in Education].

6. Bell, L. (1980). The School as an Organisation: a re-appraisal. British Journal of Sociology Of Education, 1(2), 183-192. doi: 10.1080/0142569800010204

7. Bowers, A., Ranganathan, S., \& Simmons, D. (2018). Defining Quality in Undergraduate Education. Higher Learning Research Communications, 8(1). doi: 10.18870/hlrc.v8i1.392 
8. Broh, R. (1982). Managing quality for higher profits. Montréal: McGraw-Hill.

9. Brown, S. (1957). Quality in Education. Journal of Educational Sociology, 30(8), 361. doi : 10.2307/2264767

10. Carbines, B. (1994). Quality Assurance Development and Accountability through School Reviews. In Seventh International Congress for School Effectiveness and Improvement. Melbourne.

11. Chaffee, E. \&Sherr, L. (1992). Quality. Washington: George Washington Univ.

12. Cheng, C. (1995). School education quality: conceptualization, monitoring, and enhancement. In P. Siu \& T. Tam, Quality in Education: insights from different Perspectives (pp. 123-147). HonkKong: HonkKongEducation Research Association.

13. Cheng, M. (2017). Reclaiming quality in higher education: a human factor approach. Quality in Higher Education, 23(2), 153-167. doi: 10.1080/13538322.2017.1358954

14. Cheong Cheng, Y., \& Ming Tam, W. (1997). Multi-models of quality in education. Quality Assurance in Education, 5(1), 22-31. doi: 10.1108/09684889710156558

15. Chua, C. (2004). Perception of Quality in Higher Education. In Australian Universities Quality Forum 2004. Adelaide. Retrieved from http://citeseerx.ist.psu.edu/viewdoc/download?doi=10.1.1.117.9504\&rep=rep1\&type $=$ pdf

16. Cryer, D. (1999). Defining and Assessing Early Childhood Program Quality. The Annals of The American Academy Of Political And Social Science, 563(1), 39-55. Doi:10.1177/0002716299563001003

17. Doherty, G. (2008). On quality in education. Quality Assurance in Education, 16(3), 255-265. doi:10.1108/09684880810886268

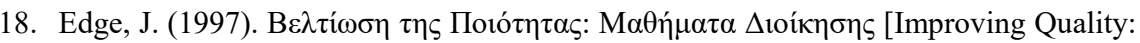

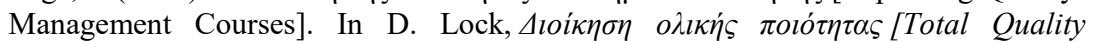
Management] (2nded.). Athens: Ellin.

19. Feigenbaum, A. (1951). Quality control: Principles, practice and administration: An industrial management tool for improving product quality and design and for reducing operating costs and losses. London: McGraw-Hill.

20. Forker, L., Vickery, S., \& Droge, C. (1996). The contribution of quality to business performance. International Journal of Operations \& Production Management, 16(8), 44-62. doi: 10.1108/01443579610125778

21. Freeman, R. (1994). Quality Assurance in Secondary Education. Quality Assurance in Education, 2(1), 21-25. doi:10.1108/09684889410054545

22. Garvin, D. (1984). What Does "Product Quality" Really Mean?. Sloan Management Review, Fall, 25-45.

23. Garvin, D. (1987). Competing in the Eight Dimensions of Quality. Harvard. Business Review, November-December, 101-109.

24. Garvin, D. (1993). Building a Learning Organization. Harvard Business Review, 71(4).

25. Gilmore, H. (1974). Product Conformance Cost. Quality Progress, 7(5), 16-19.

26. Green, D. (1994). What is Quality in Higher Education? Concepts, Policy and Practice. In D. Green, What is Quality in Higher Education? (1st ed.). Buckingham: Society for Research into Higher Education \& Open University Press.

27. Harvey, L., \& Green, D. (1993). Defining Quality. Assessment \& Evaluation in Higher Education, 18(1), 9-34. doi: 10.1080/0260293930180102

28. Ifedili, C. (2015). Instructional Supervision and Quality Assurance in schools in Nigeria. European Journal of Business and Social Sciences, 4(9), 22-29. Retrieved from http://www.ejbss.com/recent.aspx-/ 
29. Johnson, N., Wyer, R., \& Gilbert, N. (1967). Quality Education and Integration: An Exploratory Study. Phylon (1960-), 28(3), 221. doi:10.2307/273659

30. Juran, J. (1999). How to think about quality. In J. Juran \& A. Blanton Godfrey, Juran's quality handbook (5th ed.). New York: McGraw Hill.

31. Lai, K. (2003). Market orientation in quality-oriented organizations and its impact on their performance. International Journal of Production Economics, 84(1), 17-34. doi: 10.1016/s0925-5273(02)00382-1

32. Levitt, T. (1972). Production-line approach to service. Harvard Business Review, 50(5), 41-52.

33. Love, P., Li, H., Irani, Z., \& Faniran, O. (2000). Total quality management and the learning organization: a dialogue for change in construction. Construction Management and Economics, 18(3), 321-331. doi: 10.1080/014461900370681

34. Nevo, D. (1995). School-based evaluation (1st ed.). Oxford: Pergamon.

35. Nonaka, I., \& Toyama, R. (2003). The knowledge-creating theory revisited: knowledge creation as a synthesizing process. Knowledge Management Research \& Practice, 1(1), 2-10. doi: 10.1057/palgrave.kmrp.8500001

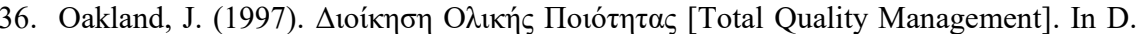

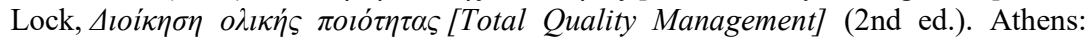
Ellin.

37. OECD. (2011). Quality framework and guidelines for OECD statistical activities. Organization for Economic Co-operation and Development. Retrieved from http://www.oecd.org/statistics/qualityframework

38. Örtenblad, A. (2015). Towards increased relevance: context-adapted models of the learning organization. The Learning Organization, 22(3), 163-181. doi: 10.1108/tlo06-2014-0027

39. Owlia, M., \& Aspinwall, E. (1996). A framework for the dimensions of quality in higher education. Quality Assurance in Education,4(2), 12-20. doi: $10.1108 / 09684889610116012$

40. Pedler, M., Burgoyne, J., \& Boydell, T. (1991). The learning company: A strategy for sustainable development. London: McGraw-Hill Publishing Co.

41. Reeves, C., \& Bednar, D. (1994). Defining Quality: Alternatives and Implications. The Academy Of Management Review, 19(3), 419. doi: 10.2307/258934

42. Schechter, C., \& Mowafaq, Q. (2013). From illusion to reality: schools as learning organizations. International Journal of Educational Management, 27(5), 505-516. doi: 10.1108/09513541311329869

43. Statistics Canada,. (2002). Statistics Canada's Quality Assurance Framework. Ottawa.

44. Tuchman, B. (1980). The decline of quality. New York Times Magazine, 2 November, $38-47$.

45. Turner, D. (2011). Quality in Higher Education. Rotterdam: Sense Publishers.

46. West-Burnham, J. (1997). Managing quality in schools: effective strategies for quality-based school improvement (2nd ed.). London: Pearson Education.

47. Westerheijden, D., Stensaker, B., \& Rosa, M. (2007). Introduction. In D. Westerheijden, B. Stensaker \& M. Rosa, Quality assurance in higher education, trends in regulation, translation and transformation (pp. 1-11). Dordrecht: Springer.

48. Winch, C. (1996). Quality and education. Oxford: Blackwell

49. Wittek, L., \& Kvernbekk, T. (2011). On the Problems of Asking for a Definition of Quality in Education. Scandinavian Journal of Educational Research, 55(6), 671684. doi: 10.1080/00313831.2011.594618

50. Yu, T., \& Wu, N. (2009). A Review of Study on the Competing Values Framework. International Journal of Business and Management, 4(7). doi: 10.5539/ijbm.v4n7p37 